\title{
Health professionals' knowledge of hospital waste sorting and storage
}

\author{
Conhecimento dos profissionais de saúde sobre triagem e acondicionamento de resíduos \\ hospitalares
}

\author{
Beatriz Edra ${ }^{1,2^{*}}$, Bruno Magalhães ${ }^{1}$, Mafalda Silva ${ }^{1}$, Maria do Céu Costa ${ }^{2}$ \\ ${ }^{1}$ Escola Superior de Saúde de Santa Maria, Travessa Antero Quental no 173/175, Porto, Portugal \\ ${ }^{2}$ CBIOS, Escola de Ciências e Tecnologias da Saúde, Universidade Lusófona, Campo Grande 376,1649-024 Lisboa, Portugal \\ *corresponding author: beatriz.edra@santamariasaude.pt
}

\begin{abstract}
The nature, diversity, and hazardousness of hospital waste (HW) require specific management procedures. Specific interventions on HW are imperative for modern societies, imposed by public and environmental health policies. The health institutions strategic management plan integrates HW management policies considering a social technic perspective process in their institutional strategic management plan, taking into account a sociotechnical perspective, based on related good practices.

Sorting is one of the most critical phases for effective management in reducing risks of generated hospital waste, more specifically at the generation site. Health professionals play an important role in this process since they participate in sorting in different contexts of clinical practice. This research aimed to identify the periodicity of contact of different health professionals such as nurses, doctors and medical assistants (MA) with HW, and their knowledge regarding the practices of sorting and storing of HW.

An observational, descriptive, and correlational cross-sectional study was developed. Data were gathered through a questionnaire applied to a sample of 1800 health professionals recruited from a Hospital Center in Porto ( Portugal). Results showed that from the $79 \%$ of health professionals who were in contact with HW, $68.7 \%$ had adequate knowledge about sorting practices. Health professionals presented more doubts in sorting and storing wastes from Groups III (Biological Hazard HW) and IV (HW of obligatory incineration)
\end{abstract}

Keywords: Hospital Waste, Sorting Practices, Knowledge, Health Professionals

\begin{abstract}
Resumo
A natureza, diversidade e perigosidade dos resíduos hospitalares (RH) exige procedimentos específicos na sua gestão. A intervenção específica sobre os RH, é incontornável na sociedade atual, pelas exigências de políticas de Saúde Pública e Ambiental. As instituições de saúde integram o processo de gestão de RH no seu plano de gestão estratégica institucional, tendo em conta uma perspetiva sociotécnica e tendo por base referenciais de boas práticas associados. A triagem é uma das fases mais importantes para a eficiência de gestão na minimização de riscos dos resíduos hospitalares produzidos, mais concretamente a triagem no local de produção. Os profissionais de saúde são elementos fulcrais nesta fase do processo pela sua participação na prática de triagem nos diferentes contextos da prática clínica. Com a presente investigação pretende-se identificar a periodicidade de contato dos diferentes profissionais de saúde, enfermeiros, médicos e auxiliares de ação médica (AAM), relativamente aos $\mathrm{RH}$ e o conhecimento dos mesmos relativamente à prática de triagem e acondicionamento de $\mathrm{RH}$.

Desenvolveu-se um estudo observacional, descritivo e correlacional de caráter transversal, utilizando como instrumento de recolha de informação um questionário aplicado a uma amostra de 1800 profissionais de saúde de um Centro Hospitalar no Porto (Portugal). Conclui-se que 79\% dos profissionais de saúde estão em contato com RH, e 68,8\% tem conhecimento adequado sobre Práticas de Triagem. Os grupos III - Resíduos Hospitalares de Risco Biológico e IVResíduos Hospitalares Específicos de incineração obrigatória, são aqueles em que os profissionais de saúde apresentam mais dúvidas na triagem e acondicionamento.
\end{abstract}

Palavras-chave: Resíduos Hospitalares, Práticas de Triagem, Conhecimento, Profissionais de Saúde 


\section{Introduction}

Over the last few years, the etiology of health problems has changed considerably, as well as the control of etiological-related factors (1). Current lifestyles, an increase in the average life expectancy, and advancements of medical practicehave lead to a more differentiated health care delivery and consequently increased production of HW (2). The nature, diversity, and hazardousness of hospital waste require specific management procedures (3). Specific interventions on hospital waste are an imperative for modern societies, imposed by public health and environmental health, and forcing health care participants to carefully reflect on their performance and to aim at an integrated management of HW $(4,5)$.

The practice of health professionals, the provision of a more differentiated health care, and the current contexts, together with the growing technological innovation, led to an increase of HW. This increase involves not only the amount of HW generated but also its characteristics, namely the composition, which has recently become more complex and dangerous $(6,7)$. This phenomenon presents hazards to both the environment and public health, mainly related to uncontrolled exposure to this type of waste, which must be minimized through a sustainable management practice $(8,9,10)$.

The multiplicity of HW producers associated with different economic activities leads to the production of very diverse, complex, and specific wastes, not only in terms of its true risks, but, considering cultural and ethical issues, also simply the perception of risk (11). The existing new concepts of waste management, the higher perception of risk associated with HW, along with the development of new treatment technologies, led to the publication of Order «No. 242/96, dated 13th August». This Order classifies the HW in four distinctive groups: Group I and II (non-hazardous waste), Group III and IV (hazardous waste).

Group I and II waste can be managed in the same way as urban waste management, since this is considered non-hazardous waste, requiring no specific management procedures. Group III present biological risk and must be pre-treated before disposal as municipal waste. Group IV waste requires incineration (8).

\section{Introdução}

Ao longo dos últimos anos a etiologia dos problemas de Saúde tem tido alterações consideráveis com o objetivo não só do controlo dos fatores etiológicos como da sua monitorização e mitigação (1). Os estilos de vida atuais, o aumento da esperança média de vida e a evolução da prática da medicina, levam a uma prestação de cuidados de saúde mais diferenciada e consequente maior produção de RH (2). A natureza, diversidade e perigosidade dos $\mathrm{RH}$ exigem procedimentos específicos na sua gestão (3). A necessidade de uma intervenção específica sobre os resíduos hospitalares obriga os participantes da rede de cuidados de saúde a refletirem no seu próprio desempenho satisfazendo as exigências de proteção da Saúde Pública e Saúde Ambiental, através de uma gestão integrada dos RH $(4,5)$.

A prática dos profissionais de Saúde e a prestação de cuidados de Saúde mais diferenciada, as caraterísticas atuais da sociedade, a par de uma crescente inovação tecnológica, conduzem a um aumento de RH. Este aumento verifica-se não só em termos quantitativos, mas também em relação às características dos próprios resíduos nomeadamente em relação à sua composição, que nos últimos tempos se torna mais complexa e com uma maior perigosidade $(6,7)$. Esta perigosidade tem riscos relacionados quer com o Ambiente quer com a Saúde Pública pelos riscos de exposição não controlado a este tipo de resíduos, que devem ser minimizados através de uma prática de gestão sustentada $(8,9,10)$.

$\mathrm{O}$ universo alargado de produtores de $\mathrm{RH}$ associado a diferentes atividades económicas conduz a uma produção de resíduos de características muito diversas, complexas e específicas, não só no que respeita ao seu risco real, mas também ao nível de questões culturais e éticas que podem ser suscitadas sobre o papel da sociedade nos ecossistemas, com base na perceção dos riscos (11). Novos conceitos de gestão de resíduos apoiados no desenvolvimento de novas tecnologias de tratamento e na maior perceção do risco intrínseco dos RH, conduziram à publicação do Despacho n. ${ }^{\circ}$ 242/96, de 13 de agosto, que classifica os $\mathrm{RH}$ em quatro grupos distintos: Grupo I- Resíduos equiparados a urbanos e Grupo II - Resíduos Hospitalares não perigosos, Grupo III - Resíduos Hospitalares de risco biológico e IV Resíduos Hospitalares Específicos (resíduos perigosos). Os resíduos pertencentes aos grupos I e II podem ter uma gestão equiparada à gestão de resíduos urbanos tendo em conta que são considerados não perigosos, não apresentam exigências específicas ao nível da sua gestão. Os resíduos do grupo III, classificados como RH de risco biológico, devem ser tratados por incineração ou 
HW management is a process that comprises several phases, which must be analysed as a system, considering a set of methodological actions. The sorting and storing are one of the most critical phases of HW Integrated Management (12), and it depends on a correct recognition and a selective deposition at the source in appropriate containers according to its characteristics and classifications (11).

The correct application of these practices are of great importance as they reduce the risk to health and the environment associated with potential contamination that could occur from the crossing of waste with associated biological risk and/or of mandatory incineration. This contamination could be caused by inappropriate pathways, or due to inadvertent mixing or the lack of knowledge of the professionals involved (8). The implementation of efficient and operational sorting and storing procedures implies an integrated management system, together with a sociotechnical perspective (13). This research aimed to identify the periodicity of contact of different health professionals with HW and their knowledge regarding the practice of sorting and storing of HW.

\section{Materials and Methods}

An observational, descriptive, correlational crosssectional study was conducted. Data were gathered through a previously validated questionnaire (2). The sampling selection considered clinical services from a Hospital Center in northern of Portugal (the largest hospital unit in the north and one of the largest in the country, representing $20 \%$ of standard patients in the North Region and $7.2 \%$ of standard patients at the national level) (1), based on the etiology of the services' functions, specifically the type of care provided potentially leading to higher production of various hospital waste, and considering the production of HW reported in the last two years (1).

The data presented here were extracted from research work in the area of HW Management (1), and are part of the overall data collected through the application of a questionnaire. The questions that were selected intended to answer questions regarding: a) frequency of contact with HW, and b) knowledge about sorting (separa- outros tratamentos apropriados e seguros para posterior eliminação como resíduos urbanos. Os resíduos do grupo IV têm de ser incinerados obrigatoriamente (8). A gestão de RH é um processo que contempla várias fases, devendo ser analisada como um sistema de gestão e controlo integrado, contemplando um conjunto de ações guiadas por referenciais metodológicos multidisciplinares. A triagem e o acondicionamento sãos das fases mais importantes na Gestão Integrada dos RH (12), operacionalizando-se num reconhecimento correto e deposição seletiva, logo na origem, em contentores apropriados, de acordo com as suas características e classificação (11).

Estas práticas desenvolvidas em contexto adequado constituem um fator de grande importância na minimização de riscos para a Saúde e para o Ambiente, associados a potenciais contaminações, resultantes do cruzamento de resíduos com risco biológico e de incineração obrigatória, induzidas por circuitos inapropriados ou por misturas inadvertidas ou, ainda, por falta de conhecimento dos profissionais envolvidos (8). A implementação de uma triagem e acondicionamento eficiente e operacional implica uma visão de gestão integrada com uma perspetiva sociotécnica (13).

Com a presente investigação pretende-se identificar a periodicidade de contato dos diferentes profissionais de saúde relativamente aos $\mathrm{RH}$ e o conhecimento dos mesmos relativamente à prática de triagem e acondicionamento de RH em ambiente hospitalar.

\section{Material e Métodos}

Para a concretização destes objetivos desenhou-se um estudo observacional, descritivo e correlacional de caráter transversal, utilizando como instrumento de recolha de informação um questionário (já validado) (2). Para seleção da amostra, foram selecionados os serviços de área clínica de um Centro Hospitalar Norte de Portugal (é a maior unidade hospitalar da região Norte e um dos maiores do País, representando 20\% dos doentes padrão da Região Norte e 7,2\% dos doentes padrão a nível Nacional) (1), tendo por base a tipologia das funções dos serviços, nomeadamente o tipo de cuidados prestados, uma potencialidade de maior produção de diferentes resíduos hospitalares, bem como a produção de RH apresentada nos dois últimos $\operatorname{anos}(1)$.

Os dados aqui apresentados foram extraídos de um trabalho de investigação mais abrangente na área da Gestão de RH (1) e dizem apenas respeito a uma parte de todos os dados recolhidos pela aplicação de questionário. Selecionaram-se aqueles que dariam 
tion and segregation) of $\mathrm{HW}$ and c) professionals with non-compliant responses and frequency of contact with HW.

Descriptive and inferential statistics were applied using the IBM SPSS $23.0^{\circledR}$ software. The frequency of contact between health professionals and HW and the percentage of suitability for sorting and storing the different HW were investigated. To carry out the analysis of sorting practices by professionals, thirteen different types of waste were considered, including the most common in hospital practice and within the different HW groups. The analysis was performed using the a) Wilcoxon-Mann-Whitney test for comparisons, where the significance level was adjusted following the Bonferroni's correction according to the comparisons established, with an adjusted significance level set at $1.67 \%$ $(5 \% / 3)$, and $b)$ the test of homogeneity of proportions (chi-square test), except when the number of observations was reduced, where Fisher's exact test was used.

\section{Results and Discussion}

The questionnaire was applied to a sample of 1800 professionals in the clinical area, medical assistants (MA), nurses, and doctors. A 44\% response rate was obtained, with 789 surveys duly validated by the different professional groups of 31 services, which corresponds to a maximum error of $3.1 \%$ (considering a simple random sample without replacement to a $95 \%$ confidence level) (1), in a sample comprised of 580 nurses, 132 medical assistants and 77 doctors, recruited from various services. The three most representative services were the Emergency Department (10.3\%), Internal Medicine $(9.6 \%)$ and the Paediatric Hospitalization Unit (6\%).

The vast majority of professionals $(98.7 \%)$ were in daily contact with hospital waste, and the frequency of contact was very high. In fact, $79 \%$ of respondents referred 'Always', followed by 'Often' (17.1\%), 'Sometimes' (2.7\%), and 'Never' (0.6\%). Notably, 'Always' and 'Frequently' together account for almost all professionals $(96.1 \%)$. A residual percentage $(0.6 \%)$ of nonresponses was also observed (Figure 1) resposta às seguintes questões: a) periodicidade de contacto com os $\mathrm{RH}, \mathrm{b}$ ) conhecimento sobre triagem (separação e acondicionamento) de $\mathrm{RH}$ e c) profissionais com respostas não conformes e periodicidade de contato com RH.

Os dados foram tratados com recurso à estatística descritiva e inferencial, recorrendo ao software IBM SPSS $23.0^{\circledR}$. Pesquisou-se a frequência de contato dos profissionais de saúde com os $\mathrm{RH}$ e a percentagem de adequabilidade da triagem e acondicionamento dos diferentes RH. Para realizar esta avaliação das práticas de triagem por parte dos profissionais, foram utilizados treze tipos de resíduos diferentes, os mais comuns na prática hospitalar e pertencentes aos diferentes grupos de RH. Recorreu-se para esta análise aos seguintes testes: a) teste de Wilcoxon-Mann-Whitney para realização de comparações. Devido às comparações realizadas, o nível de significância foi ajustado segundo a correção de Bonferroni, de que resulta um nível de significância ajustado estabelecido em 1.67\% (5\%/3), $\mathrm{e} ; \mathrm{b}$ ) teste da homogeneidade das proporções (teste do qui-quadrado), quando o número de observações era reduzido recorre-se ao teste exato de Fisher.

\section{Resultados e Discussão}

O questionário foi aplicado a uma amostra de 1800 profissionais da área clínica, Auxiliares de ação médica (AAM), Enfermeiros e Médicos, dos quais se obteve uma taxa de resposta de $44 \%$, com 789 inquéritos devidamente validados dos diversos grupos profissionais de 31 serviços, que corresponde a um erro máximo de 3,1\% (considerando uma amostra aleatória simples sem reposição para um nível de confiança de 95\%) (1). Correspondente a uma amostra composta por 580 enfermeiros, 132 auxiliares de ação médica e 77 médicos, de vários serviços, sendo os três mais representativos o serviço de Urgência (10,3\%), a Medicina interna $(9,6 \%)$ e o internamento de Pediatria (6\%). A frequência de contacto com os RH por parte dos profissionais (Figura 1) é um aspeto relevante na avaliação das práticas relacionadas com os RH tendo em conta que potencia o risco de exposição ocupacional. A grande maioria dos profissionais $(98,7 \%)$ está em contacto, no dia-a-dia, com resíduos hospitalares, sendo a frequência com que o fazem muito elevada. Com efeito, "Sempre" é a resposta maioritária 79\%, seguindo-se "Frequentemente" 17,1\%, "Às vezes" $2,7 \%$ e "Nunca" $0,6 \%$. Note-se que "Sempre" e "Frequentemente" em conjunto, representam a quase totalidade dos profissionais $(96,1 \%)$. Existe também um número muito reduzido de não respostas $0,6 \%$. 
The analysis by professional category showed significant differences between professions. The majority of doctors (51.9\%) reported 'Always', followed by 'Often' (39\%), 'Sometimes' (7.8\%) and 'Never' (1.3\%), with no non-responses found. 'Always' and 'Frequently' together represented almost $90.9 \%$ of all doctors. The majority of nurses $(83.4 \%)$ reported 'Always', followed by 'Often' (14.3\%), 'Sometimes' (1.6\%), with 'Never' scoring zero responses and with four $(0.7 \%)$ non-answers found. Again, the responses 'Always' and 'Frequently' together represented almost all nurses $(97.7 \%)$. The majority of medical assistants reported 'Always' (75\%), followed by 'Often' (16.7\%), 'Sometimes' $(4.5 \%)$ and 'Never' (3\%), with one non-response found $(0.8 \%)$.

Similarly, 'Always' and 'Frequently' together represented the majority of medical assistants (96.1\%). Although 'Always' and 'Frequently' scored higher for the three professions (doctors, nurses, and medical assistants), the frequencies of both responses were substantially different between them. Thus, the chi-square test was used to test the homogeneity of responses, more specifically to test whether the distribution of responses was the same for all professions. The significance level was set at 5\%. The test statistic (chi-square of 4 degrees of freedom) was $53.3(\mathrm{p}<0.001)$. Therefore, the previous finding was confirmed, with statistically significant
Analisando por categoria profissional verificamos que existem diferenças importantes entre as profissões. Para os Médicos (Figura 1), "Sempre" é a resposta maioritária 51,9\%, seguindo-se "Frequentemente" $39 \%$, "Às vezes" 7,8\% e "Nunca"1,3\%, não existindo quaisquer não respostas. Note-se que "Sempre" e "Frequentemente" em conjunto, representam a quase totalidade dos Médicos 90,9\%. Para os Enfermeiros (Figura 2), "Sempre" é a resposta maioritária 83,4\%, seguindo-se "Frequentemente" 14,3\%, "Às vezes" $1,6 \%$, não existindo quaisquer respostas "Nunca" e existindo 4 não respostas $0,7 \%$. Note-se que "Sempre" e "Frequentemente" em conjunto, representam a quase totalidade dos Enfermeiros 97,7\%.

Para os Auxiliares de ação médica (Figura 1), "Sempre" é a resposta maioritária 75\%, seguindose "Frequentemente" 16,7\%, "Às vezes" 4,5\% e "Nunca" 3\%, existindo uma não resposta $0,8 \%$. Notese que "Sempre" e "Frequentemente" em conjunto, representam a quase totalidade dos Auxiliares 96,1\%.

Apesar de as respostas "Sempre" e "Frequentemente" serem as mais importantes (por esta ordem) para as três profissões, existem também claras diferenças entre estas. Com efeito, as frequências de ambas as respostas são substancialmente diferentes para as três profissões. Neste contexto, recorre-se ao teste do qui-quadrado para testar a homogeneidade das respostas, ou seja, para testar se a distribuição das respostas é igual para todas as profissões, adotando-se um nível de significância de $5 \%$. A estatística do teste (qui-quadrado de 4 graus de

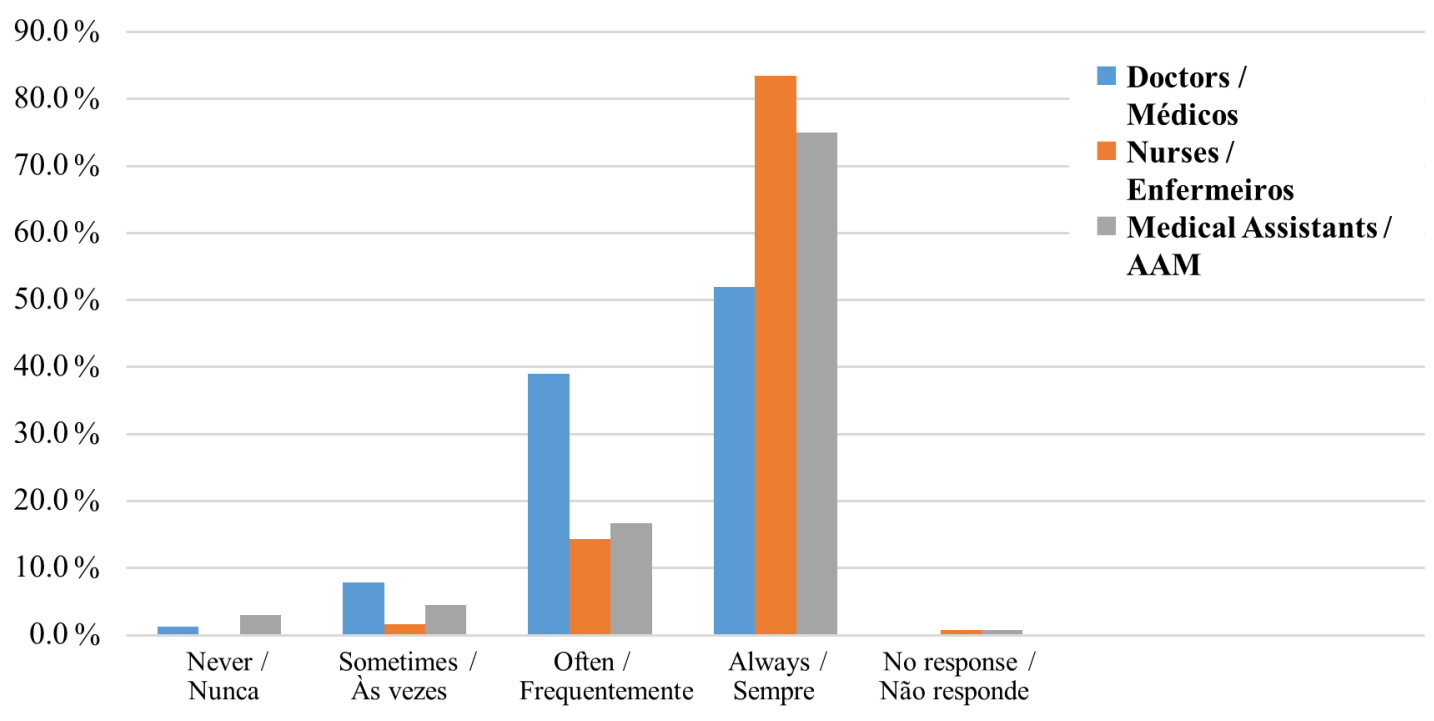

Contact Frequency / Frequência de Contato

Figure 1 - Contact of Health Professionals with HW (By professional category)

Figura 1 - Contacto dos Profissionais de Saúde (por categoria profissional). 
differences between the distribution of responses from the three professions. A detailed analysis was performed to compare pairs of professions, i.e., to compare doctors with nurses, doctors with medical assistants, and nurses with medical assistants. Since the response categories 'Never', 'Sometimes', 'Often' and 'Always' are an ordinal qualitative variable, the Wilcoxon-Mann-Whitney test was used for these comparisons. Importantly, the significance level was set at $5 \% / 3 \approx 1.67 \%$. The values of the test statistics and corresponding p-values for the above comparisons were, respectively, 17910 (0.000), 6928 (0.001), and 207410 (0.012). In sum, doctors had less contact with hospital waste than nurses and assistants, and nurses had more contact than medical assistants. Nurses were found to be the professionals more frequently exposed to hospital waste, followed by medical assistants and doctors.

Similarly, studies conducted previously $(3,14)$, concluded that nurses are the professionals who are more frequently exposed to HW. Although MA are responsible for the collection of HW, the daily activity of nurses includes a set of procedures most likely to generate HW, thus potentially increasing their exposure. As for Doctors, their clinical practices involve a set of tasks which do not always generate HW. Moreover, some specific tasks that may generate HW are always supported by nurses and MA, and these are mostly observed in surgical interventions or more invasive procedures.

To analyse the sorting and storing practices of the professionals, questions were asked regarding the storage of thirteen types of HW commonly found in hospital practice and classified within different groups (I-IV).

The results are displayed according to each professional category in Table 1. The frequency of responses of the appropriately colored waste storage containers according to the group risk category is shown for each profession, enabling their comparison. liberdade) é 53,3 ( $\mathrm{p}<0,001)$, pelo que, confirmando a constatação anterior, se conclui que existem diferenças significativas entre a distribuição das respostas das três profissões. Para detalhar esta análise, procede-se ainda à comparação dos pares de profissões, ou seja, comparase os médicos com os enfermeiros, os médicos com os auxiliares de ação médica e os enfermeiros com os auxiliares de ação médica. Uma vez que as categorias de resposta ("Nunca", "Às vezes", "Frequentemente" e "Sempre") constituem uma variável qualitativa ordinal, recorre-se ao teste de Wilcoxon-MannWhitney para estas comparações. Note-se que, devido a estas três comparações, o nível de significância tem que ser ajustado segundo a correção de Bonferroni, de que resulta um nível de significância ajustado de $5 \% / 3 \approx 1,67 \%$. Os valores das estatísticas do teste e correspondentes valores-p para as três comparações indicadas acima são respetivamente $17910(0,000)$, $6928(0,001)$ e $207410(0,012)$, concluindo-se que os médicos têm menor contacto com resíduos hospitalares do que os enfermeiros e do que os auxiliares, e que os enfermeiros têm mais contacto do que os auxiliares. Os enfermeiros são os profissionais que têm contacto com os resíduos mais frequentemente, seguindo-se os auxiliares e os médicos.

Outros estudos já realizados $(3,14)$, concluíram, igualmente, que os Enfermeiros são os profissionais que têm maior contacto com RH. Apesar de os AAM serem os responsáveis pela recolha dos $\mathrm{RH}$, os Enfermeiros são os profissionais que no exercício da sua prática clínica desempenham um conjunto de procedimentos dos quais resultam na sua maioria $\mathrm{RH}$ potenciando desta forma esse contacto com maior frequência. Em relação aos Médicos, a sua prática clínica envolve um conjunto de tarefas de que nem sempre resultam RH e naquelas em que na sua execução resultam, têm sempre o apoio de Enfermagem e dos AAM. Esta situação verifica-se essencialmente em termos de intervenção cirúrgica ou procedimentos mais invasivos.

De forma a analisar as práticas de triagem e acondicionamento por parte dos profissionais foi colocada uma questão relativamente ao acondicionamento de treze tipos de $\mathrm{RH}$, pertencentes aos quatro grupos de $\mathrm{RH}$, mais comuns na prática hospitalar.

Os resultados relacionados com esta avaliação estão representados por categoria profissional na Tabela 1 , nomeadamente a frequência das respostas às categorias de recipientes de acondicionamento de resíduos de acordo com as suas características, enunciando as frequências totais e frequências para cada profissão, de modo a permitir comparar as três profissões. 
1 - Rejected Medication (Group IV, red container)

Differences between professions were found and the answer 'White container' scored the highest (47.8\%), followed by 'Red container' (35.7\%), 'Black container' (7.1\%), and 'Do not know' (6.5\%), with 23 nonresponses $(2.9 \%)$ (Table 1$)$. The chi-square test was used to test the homogeneity of responses, with a significance level set at 5\%. The test statistic (chi-square of 6 degrees of freedom) is 109.91, with a p-value of approximately 0 , showing that there are significant differences between the professions concerning waste storing (Table 1). The pairs of professions were compared, namely doctors and nurses, doctors and medical assistants, and nurses, and medical assistants. The values of the chi-square statistics (3 degrees of freedom) and corresponding p-values were, respectively, 113.6 (0.000), $14.8(0.002)$ and 29.0 (0.000), enabling us to conclude that the distributions were different for the three professions. Due to these three comparisons, the significance level was adjusted according to Bonferroni's correction, with an adjusted significance level set at $1.67 \%(5 \% / 3)$. These residues must be stored in the red container. Results showed a low percentage (35.7\%) of participants answered this question correctly, with a $95 \%$ confidence interval of $[0.324,0.392]$. Doctors, nurses, and medical assistants scored $18.2 \%$ [CI 0.106; 0.290 ], 39\% [CI 0.350; 0.431] and 31.8\% [CI 0.241; $0.406]$, respectively. The homogeneity test was used to compare the percentage of success in storing between the three professions. The statistic test (chi-square of 2 degrees of freedom) was 13.8 , with a p-value of 0.001 , showing significant differences between the percentages of success in the storing of waste of the three professions. The pairs of professions were also compared, applying the values of the chi-square statistics ( $1 \mathrm{de}$ gree of freedom) and corresponding p-values of 11.8 (0.001), $3.9(0.047)$ and $2.0(0.153)$ for the comparison of doctors with nurses, doctors with medical assistants and nurses with medical assistants, respectively. Consequently, when comparing the p-values with the significance level adjusted by the Bonferroni correction (1.67\%), it was possible to conclude that the percentage of correct storing by doctors is lower than nurses and equal to medical assistants and that nurses and medical assistants showed the same proportions.
1 - Fármacos (medicamentos) rejeitados (Grupo IV) O "Recipiente branco" é a resposta mais frequente (47,8\%), seguindo-se o "Recipiente vermelho" (35,7\%), o "Recipiente preto" (7,1\%) e "Não sabe" (6,5\%), existindo 23 não respostas (2,9\%), e verificando-se que existem diferenças entre as profissões (Tabela 1). Neste contexto, recorre-se ao teste do qui-quadrado para testar a homogeneidade das respostas, adotandose um nível de significância de 5\%. A estatística do teste (qui-quadrado de 6 graus de liberdade) é 109,91 $(p<0,001)$ pelo que se conclui que existem diferenças significativas entre as profissões no acondicionamento dos resíduos (Tabela 1). Procedeu-se à comparação dos pares de profissões, ou seja, compara-se os médicos com os enfermeiros, os médicos com os auxiliares de ação médica e os enfermeiros com os auxiliares de ação médica. Os valores das estatísticas do qui-quadrado (3 graus de liberdade) e correspondentes valores- $\mathrm{p}$ são respetivamente $113,6(0,000), 14,8(0,002)$ e 29,0 $(0,000)$, pelo que se conclui que as distribuições são diferentes nas três profissões. Note-se que, devido a estas três comparações, o nível de significância tem que ser ajustado segundo a correção de Bonferroni, de que resulta um nível de significância ajustado de $5 \% / 3 \approx 1,67 \%$. Estes resíduos, fármacos (medicamentos) rejeitados, devem ser acondicionados no recipiente vermelho, sendo importante avaliar a proporção de sucessos no acondicionamento, ou seja, a proporção de profissionais que os acondicionam corretamente. A proporção dos profissionais que os acondicionam corretamente é apenas de $35,7 \%$, um valor que pode ser considerado baixo, com um intervalo de confiança [I.C].a 95\% de 0,$324 ; 0,392$, sendo para os médicos, os enfermeiros e os auxiliares de ação médica respetivamente de $18,2 \%$ [I.C. 0,106; 0,290], 39\% [I.C.0,350;0,431] e $31,8 \%$ [I.C. 0,241; 0,406]. Para comparar a proporção de sucessos no acondicionamento das três profissões, recorre-se ao teste da homogeneidade. A estatística do teste (qui-quadrado de 2 graus de liberdade) é 13,8, com um valor-p de 0,001 , pelo que se conclui que existem diferenças significativas entre as proporções de sucessos no acondicionamento dos resíduos das profissões. Procedeu-se também à comparação dos pares de profissões, sendo os valores das estatísticas do qui-quadrado (1 grau de liberdade) e correspondentes valores-p de $11,8(0,001), 3,9(0,047)$ e $2,0(0,153)$ para a comparação de médicos com enfermeiros, médicos com auxiliares de ação médica e de enfermeiros com auxiliares de ação médica respetivamente. Consequentemente, comparando os valores-p com o nível de significância ajustado pela correção de Bonferroni $(1,67 \%)$, conclui-se que a percentagem de 


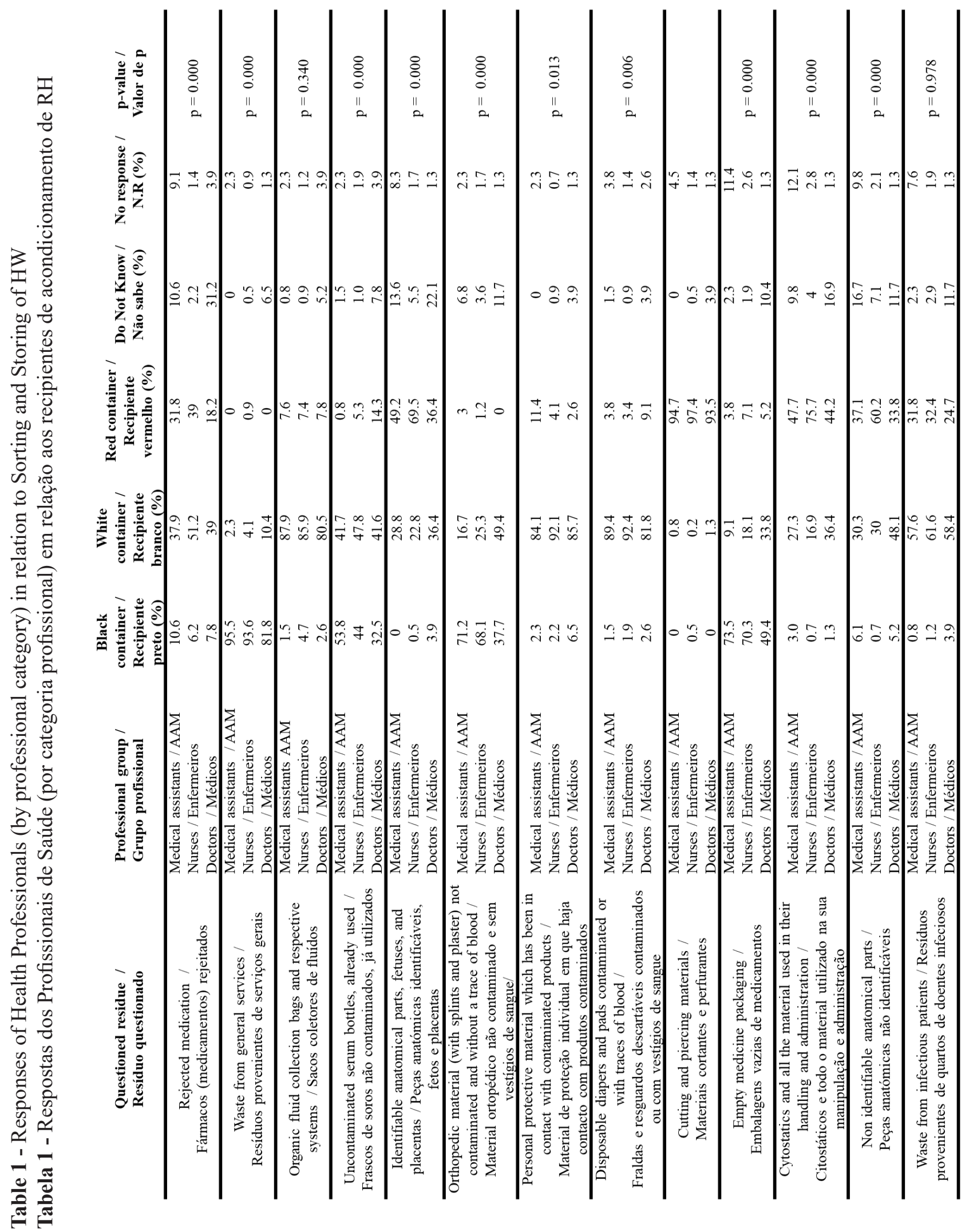


2 - Waste from general services (such as offices, meeting rooms, toilets, among others) (Group II, black container)

Most of the respondents indicated the 'Black container' (92.8\%), followed by the 'White container' $(4.4 \%)$, 'Do not know' ( $1 \%)$ and the 'Red container' $(0.6 \%)$, with nine non-responses (1.1\%) (Table 1).

The statistics of the test of homogeneity of responses was $19.4(p<0.001)$ (Table 1$)$, revealing significant differences in waste storing between the professions. For the comparison of doctors with nurses, doctors with medical assistants, and nurses with medical assistants, the chi-square statistics values and corresponding $\mathrm{p}$ values were 12.2 (0.000), 12.5 (0.000), and 1.7 (0.192), respectively. These results show a different distribution for doctors, nurses, and assistants. From this analysis, it can be inferred that no significant distribution was found between nurses and assistants.

These residues must be stored in the black container. The percentage of professionals who disposed of it correctly was $92.8 \%$ [CI $0.907 ; 0.944]$. Doctors, nurses and medical assistants reached $81.8 \%$ [CI $0.710 ; 0.894$ ], $93.6 \%$ [CI 0.912; 0.954] and 95.5\% [CI 0.899; 0.981], respectively. These results are relatively high, and the last two scores are close to 1. To compare how well each group of professionals succeeded in waste storage, the homogeneity test statistic (chi-square of 2 degrees of freedom) was $15.8(\mathrm{p}<0.001)$, with a $\mathrm{p}$-value of approximately 0 . These findings show significant differences between the proportion of success of the professionals regarding waste storage. For the comparison of the pairs of professions, the values of the chi-square statistics (1 degree of freedom) and corresponding pvalues were $11.6(0.001), 8.9(0.003)$ and $0.36(0.551)$ for the comparison of doctors with nurses, doctors with medical assistants and nurses with medical assistants, respectively. These data reveal that the percentage of correct waste storing by doctors was lower than that of nurses and assistants and that latter two groups showed equal percentages. acondicionamento correto dos médicos é inferior à dos enfermeiros e igual à dos auxiliares e que as proporções dos dois últimos são iguais.

2 - Resíduos provenientes de serviços gerais (como gabinetes, salas de reunião, instalações sanitárias, etc.) (Grupo II)

O "Recipiente preto" é a resposta maioritária $(92,8 \%)$, seguindo-se o "Recipiente branco" (4,4\%), "Não sabe" $(1 \%)$ e o "Recipiente vermelho" $(0,6 \%)$, existindo 9 não respostas $(1,1 \%)$ (Tabela 1$)$.

A estatística do teste da homogeneidade das respostas é 19,4 ( $\mathrm{p}<0,001)$ (Tabela 1), pelo que se conclui que existem diferenças significativas entre as profissões no acondicionamento dos resíduos. Para a comparação dos médicos com os enfermeiros, dos médicos com os auxiliares de ação médica e dos enfermeiros com os auxiliares de ação médica, os valores das estatísticas do qui-quadrado e correspondentes valores-p são respetivamente $12,2(0,000), 12,5 \quad(0,000)$ e 1,7 $(0,192)$. Conclui-se que as distribuições no caso dos médicos são diferentes quer das dos enfermeiros, quer das dos auxiliares e admite-se que as distribuições destes dois últimos não se distinguem entre si. Estes resíduos provenientes de serviços gerais devem ser acondicionados no recipiente preto, o que também permite avaliar a proporção de profissionais que os acondicionam corretamente. A proporção é de $92,8 \%$, um valor muito elevado, [I.C.0,907; 0,944], sendo para os médicos, os enfermeiros e os auxiliares de ação médica respetivamente de $81,8 \%$ [I.C.0,710; 0,894], 93,6\% [I.C.0,912;0,954] e 95,5\% [I.C.0,899; 0,981]. São proporções muito elevadas, sendo as duas últimas próximas de 1. Para comparar a proporção de sucessos no acondicionamento das três profissões, a estatística do teste da homogeneidade (qui-quadrado de 2 graus de liberdade) é $15,8(\mathrm{p}<0,001)$, pelo que se conclui que existem diferenças significativas entre as proporções de sucessos no acondicionamento dos resíduos das profissões. Para a comparação dos pares de profissões, os valores das estatísticas do qui-quadrado (1 grau de liberdade) e correspondentes valores-p são 11,6 $(0,001), 8,9(0,003)$ e $0,36(0,551)$ para a comparação de médicos com enfermeiros, médicos com auxiliares de ação médica e de enfermeiros com auxiliares de ação médica respetivamente. Conclui-se que a proporção de acondicionamento correto pelos médicos é inferior à dos enfermeiros e à dos auxiliares e que as proporções dos dois últimos são iguais. 
3 - Organic fluid collection bags and respective systems (Group III, white container)

The 'White container' was the most predominant answer $(85.7 \%)$, followed by the 'Red container' $(7.5 \%)$, the 'Black container' (3.9\%) and 'Do not know' (1.3\%), with 13 non-responses found (1.6\%).

The statistics for the homogeneity of responses test was $2.2(p=0.340)$, so one can infer that there no differences were found between the three professions in waste storing (Table 1). These residues must be stored in a white container, and the percentage of professionals storing it correctly was of $85.7 \%$ [CI $0.830 ; 0.880$ ]. Individual scores were also high, $80.5 \%$ [CI $0.696 ; 0.883$ ], $85.9 \%$ [CI $0.827 ; 0.885$ ] and $87.9 \%$ [CI $0.808 ; 0.927$ ], for doctors, nurses, and medical assistants respectively.

To compare the proportion of success of the three professions in waste storing, the homogeneity test statistic (chi-square of 2 degrees of freedom) was $2.2(p=0.332)$, indicating that no significant differences were found in the proportion of success in waste storing by the three professions.

4 - Uncontaminated and used serum bottles (Group II black container)

'White container' was the most frequent answer (46.1\%), followed by 'Black container' (44.5\%), 'Red container' (5.4\%) and 'Do not know' (11.8\%), with 17 non-responses $(2.2 \%)$ found (Table 1$)$.

The statistics for the homogeneity of the responses test was $35.4(p<0.001)$, with a $p$-value of approximately 0 , indicating that significant differences were found in waste storing by the professions. For the comparison of doctors with nurses, doctors with medical assistants, and nurses with medical assistants, the values of the chi-square statistics and corresponding p-values were 23.4 (0.000), 24.8 (0.000), and 6.4 (0.042), respectively. These data show that the distributions found for doctors are different from both nurses and assistants and that the distributions of the latter two are not significant.

These residues must be stored in the black container. The percentage of professionals who stored them correctly was only $46.1 \%$, [CI $0.426 ; 0.497$ ]. Doctors, nurses and medical assistants scored $41.6 \%$, [CI 0.306; 0.534 ]; 47.8\% [CI 0.436; 0.519]; and 41.7\% [CI 0.333; $0.506]$, respectively. To compare the proportion of success in the storing of the three professions, the homogeneity test statistic (chi-square of 2 degrees of freedom) was 2.3 ( $p=0.313$ ), suggesting that no significant differences were found between the proportion of success in waste storing regarding the three professions.
3 - Sacos coletores de fluídos orgânicos e respetivos sistemas (Grupo III)

O "Recipiente branco" é a resposta maioritária $(85,7 \%)$, seguindo-se o "Recipiente vermelho" (7,5\%), o "Recipiente preto" (3,9\%) e "Não sabe" (1,3\%), existindo 13 não respostas $(1,6 \%)$ (Tabela1).

A estatística do teste da homogeneidade das respostas é 2,2 ( $\mathrm{p}=0,340)$, pelo que se admite que não existem diferenças entre as três profissões no acondicionamento dos resíduos (Tabela 1). Estes resíduos devem ser acondicionados no recipiente branco, pelo que a proporção de profissionais que os acondicionam corretamente é de $85,7 \%$ [I.C. 0,830;0,880] sendo para os médicos, os enfermeiros e os auxiliares de ação médica respetivamente de $80,5 \%$ [I.C.0,696;0,883], $85,9 \%$ [I.C.0,827; 0,885] e 87,9\% [I.C.0,808; 0,927], sendo proporções elevadas.

Para comparar a proporção de sucessos no acondicionamento das três profissões, a estatística do teste da homogeneidade (qui-quadrado de 2 graus de liberdade) é 2,2 ( $\mathrm{p}=0,332$ ), pelo que se conclui que não existem diferenças significativas entre as proporções de sucessos no acondicionamento dos resíduos constituídos por sacos coletores de fluídos orgânicos e respetivos sistemas das três profissões.

4 - Frascos de soros não contaminados, já utilizados (Grupo II)

O "Recipiente branco" é a resposta mais frequente (46,1\%), seguindo-se o "Recipiente preto" (44,5\%), o "Recipiente vermelho" (5,4\%) e "Não sabe" $(11,8 \%)$, existindo 17 não respostas (2,2\%) (Tabela1).

A estatística do teste da homogeneidade das respostas é $35,4(p<0,001)$ peloque se conclui que existem diferenças significativas entre as profissões no acondicionamento dos resíduos (Tabela1). Para a comparação dos médicos com os enfermeiros, dos médicos com os auxiliares de ação médica e dos enfermeiros com os auxiliares de ação médica, os valores das estatísticas do qui-quadrado e correspondentes valores-p são respetivamente 23,4 $(0,000), 24,8(0,000)$ e $6,4(0,042)$, pelo que se conclui que as distribuições no caso dos médicos são diferentes quer das dos enfermeiros, quer dos auxiliares e admitese que as distribuições destes dois últimos não se distinguem entre si.

Estes resíduos constituídos por frascos de soros não contaminados, já utilizados devem ser acondicionados no recipiente preto, pelo que a proporção de profissionais que os acondicionam corretamente é de 46,1\%, [I.C.0,426; 0,497], sendo para os médicos, os enfermeiros e os auxiliares de ação médica respetivamente de 41,6\%, [I.C.0,306; 0,534], 47,8\% [I.C.0,436; 0,519] e 41,7\% [I.C.0,333; 0,506], sendo 
5 - Identifiable anatomical parts, foetuses and placentas (Group IV, red container)

'Red container' scored the highest (62.9\%), followed by 'White container' (25.1\%), 'Do not know' (8.5\%) and 'Black container' $(0.8 \%)$, with 22 non-responses $(2.8 \%)$ found (Table 1). The statistics for the homogeneity of responses test was $50.9(\mathrm{p}<0.001)$, with a $\mathrm{p}$-value of approximately 0 , therefore suggesting that significant differences were found in waste storing by the professions. For the comparison of doctors with nurses, doctors with medical assistants, and nurses with medical assistants, the chi-square statistics values and corresponding p-values were 44.0 (0.000), 5.5 (0.065) and $18.5(0.000)$, respectively. This enables the conclusion that the distribution for doctors was different from nurses, but did not show differences in the distribution of medical assistants, revealing different distributions for the latter two.

These residues must be stored in the red container, and the percentage of professionals who stored them correctly was $62.9 \%$, showing a moderate value [CI 0.594 ; $0.662]$. Doctors, nurses and medical assistants scored $36.4 \%$ [CI 0.259; 0.482]; 69.5\% [CI 0.655; 0.732]; and $49.2 \%$ [CI $0.405 ; 0.580]$, respectively. The percentage of nurses is moderate, with the other two being low, especially that of doctors, which is quite low.

To compare the proportion of success in the storing of the three professions, the homogeneity test statistic (chi-square of 2 degrees of freedom) is 44.5 ( $p<0.001$ ); therefore it is concluded that there are significant differences between the proportion of success in the storing of waste by the professionals. For the comparison of the pairs of professions, the values of the chi-square statistics (1 degree of freedom) and corresponding pvalues were $31.6(0.000), 2.8(0.096)$, and 18.7 (0.000), for the comparison of doctors with nurses, doctors with medical assistants and nurses with medical assistants, respectively. It was possible to conclude that the percentage of correct storage by doctors is lower than by nurses but equal to that of medical assistants and that the percentage of proper storage by nurses is higher than storage by assistants. proporções baixas. Para comparar a proporção de sucessos no acondicionamento das três profissões, foi aplicada a estatística do teste da homogeneidade (quiquadrado de 2 graus de liberdade) que é $2,3(\mathrm{p}=0,313)$, pelo que se conclui que não existem diferenças significativas entre as proporções de sucessos no acondicionamento dos resíduos das três profissões.

5 - Peças anatómicas identificáveis, fetos e placentas (Grupo IV)

O "Recipiente vermelho" é a resposta maioritária $(62,9 \%)$, seguindo-se "Recipiente branco" $(25,1 \%)$, "Não sabe" (8,5\%)e "Recipientepreto"( $0,8 \%)$, existindo 22 não respostas $(2,8 \%)$ (Tabela 1$)$. A estatística do teste da homogeneidade das respostas é 50,9 ( $\mathrm{p}<0,001)$, pelo que se conclui que existem diferenças significativas entre as profissões no acondicionamento dos resíduos (Tabela 1). Para a comparação dos médicos com os enfermeiros, dos médicos com os auxiliares de ação médica e dos enfermeiros com os auxiliares de ação médica, os valores das estatísticas do qui-quadrado e correspondentes valores-p são respetivamente 44,0 $(0,000), 5,5(0,065)$ e $18,5(0,000)$, pelo que se conclui que a distribuição no caso dos médicos é diferente da dos enfermeiros, mas não se distingue da distribuição dos auxiliares e que as distribuições destes dois últimos são diferentes.

Estes resíduos constituídos por peças anatómicas identificáveis, fetoseplacentas devemseracondicionados no recipiente vermelho, pelo que a proporção de profissionais que os acondicionam corretamente é de $62,9 \%$, um valor moderado [I.C.0,594; 0,662], sendo para os médicos, os enfermeiros e os auxiliares de ação médica respetivamente de $36,4 \%$ [I.C.0,259; 0,482], $69,5 \%$ [I.C.0,655; 0,732] e 49,2\% [I.C.0,405; 0,580]. A proporção dos enfermeiros é moderada, sendo as outras duas baixas, especialmente a dos médicos, que é mesmo bastante baixa.

Para comparar a proporção de sucessos no acondicionamento pelas três profissões, a estatística do teste da homogeneidade (qui-quadrado de 2 graus de liberdade) é 44,5 ( $p<0,001)$, pelo que se conclui que existem diferenças significativas entre as proporções de sucessos no acondicionamento dos resíduos das profissões. Para a comparação dos pares de profissões, os valores das estatísticas do qui-quadrado (1 grau de liberdade) e correspondentes valores-p são 31,6 $(0.000), 2,8(0,096)$ e $18,7(0,000)$ para a comparação de médicos com enfermeiros, médicos com auxiliares de ação médica e de enfermeiros com auxiliares de ação médica respetivamente. Conclui-se que a proporção de acondicionamento correto dos médicos é inferior à 
6 - Orthopaedic material (such as splints and plaster) not contaminated and without a trace of blood (Group II, black container)

The majority of respondents indicated 'Black container' (65.7\%), followed by 'White container' (26.2\%), 'Do not know' (4.9\%) and 'Red container' (1.4\%), with 14 non-responses $(1.8 \%)$ found (Table 1$)$. The statistics for the homogeneity of responses test was $38.8(\mathrm{p}<0.001)$, with a p-value of approximately 0 . This enables the conclusion that significant differences were found in waste storing by the professions (Table 1). For the comparison of doctors with nurses, doctors with medical assistants, and nurses with medical assistants, the chi-square statistics values and corresponding p-values were 28.3 (0.000), 27.5 (0.000), and 8.3 (0.016), respectively; therefore it was possible to conclude that the distributions were different for the three professions. These residues must be stored in the black container, and data show a moderate value of $65.7 \%$ (or 518 professionals) disposed of them correctly, [CI 0.622; 0.689]. Doctors, nurses, and medical assistants scored $37.7 \%$ [CI $0.271 ; 0.495$ ]; $68.1 \%$ [CI $0.641 ; 0.718$ ]; and $71.2 \%$ [CI $0.626 ; 0.786]$, respectively. The percentage of doctors was low and moderate for nurses and medical assistants. To compare the proportion of success in the waste storing by the three professions, the homogeneity test statistic (chi-square of 2 degrees of freedom) was 30.1 $(p<0.001)$, with a $p$-value of approximately 0 . These results showed significant differences between the proportion of success in waste storing by the professionals. For the comparison of the pairs of professions, the values of the chi-square statistics (1 degree of freedom) and corresponding p-values were $26.2(0.000), 21.2$ $(0.000)$ and $0.35(0.555)$ for the comparison of doctors with nurses, doctors with medical assistants and nurses with medical assistants, respectively. It was possible to conclude that the percentage of correct waste storing by doctors was lower than that of nurses and assistants and that the latter two showed equal percentages.

7. Personal protective equipment which has been in contact with contaminated products (such as gloves, masks) (Group III, white container)

'White container' scored the highest (90.1\%), followed by 'Red container' (5.2\%), 'Black container' (2.7\%) and 'Do not know' (1\%), with eight non-responses found (1\%) (Table 1).

The statistics for the homogeneity of responses test was 12.7 ( $\mathrm{p}=0.013$ ), enabling the conclusion that there were significant differences in waste storing by the professionals. For the comparison of doctors with nurses, doctors with medical assistants, and nurses with medical assistants, the values of the chi-square statistics and dos enfermeiros, mas é igual à dos auxiliares e que a proporção dos enfermeiros é superior à dos auxiliares.

6 - Material ortopédico (como talas e gesso) não contaminado e sem vestígios de sangue (Grupo II)

O "Recipiente preto" é a resposta maioritária $(65,7 \%)$, seguindo-se "Recipiente branco" (26,2\%), "Não sabe" $(4,9 \%)$ e "Recipiente vermelho" (1,4\%), existindo 14 não respostas $(1,8 \%)$ (Tabela 1$)$. A estatística do teste da homogeneidade das respostas é 38,8 ( $\mathrm{p}<0,001)$, pelo que se conclui que existem diferenças significativas entre as profissões no acondicionamento dos resíduos (Tabela 1). Para a comparação dos médicos com os enfermeiros, dos médicos com os auxiliares de ação médica e dos enfermeiros com os auxiliares de ação médica, os valores das estatísticas do qui-quadrado e correspondentes valores-p são respetivamente 28,3 $(0,000), 27.5(0,000)$ e $8,3(0,016)$, pelo que se conclui que as distribuições são diferentes nas três profissões.

Estes resíduos de material ortopédico (como talas e gesso) não contaminado e sem vestígios de sangue devem ser acondicionados no recipiente preto, pelo que a observação do quadro mostra que a proporção de profissionais que os acondicionam corretamente é de $65,7 \%$ (ou 518 profissionais), um valor moderado, com [I.C. 0,622; 0,689], sendo para os médicos, os enfermeiros e os auxiliares de ação médica respetivamente de $37,7 \%$ [I.C.0,271; 0, 495], 68,1 [I.C. 0,$641 ; 0,718$ ] e 71,2\% [I.C.0,626; 0.786]. A proporção dos médicos é baixa, sendo as outras duas moderadas. Para comparar a proporção de sucessos no acondicionamento pelas três profissões, a estatística do teste da homogeneidade (qui-quadrado de 2 graus de liberdade) é $30,1 \quad(p<0,001)$, pelo que se conclui que existem diferenças significativas entre as proporções de sucessos no acondicionamento dos resíduos em função das profissões. Para a comparação dos pares de profissões, os valores das estatísticas do qui-quadrado (1 grau de liberdade) e correspondentes valores-p são 26,2 $(0,000), 21,2(0,000)$ e $0,35(0,555)$ para a comparação de médicos com enfermeiros, médicos com auxiliares de ação médica e de enfermeiros com auxiliares de ação médica respetivamente. Conclui-se que a proporção de acondicionamento correto pelos médicos é inferior à dos enfermeiros e à dos auxiliares e que as proporções destes dois últimos são iguais.

7 - Material de proteção individual em que haja contacto com produtos contaminados (como luvas, máscaras) (Grupo III)

O "Recipiente branco" é a resposta maioritária (90,1\%), seguindo-se "Recipiente vermelho" (5,2\%), 
corresponding p-values were $5.1(0.078), 0.9$ (0.351), and 6.7 (0.009), respectively. These findings suggest that no differences were found for the distribution between doctors and the other two professions, while the distributions of nurses and assistants were different.

These residues must be stored in the white container. A high percentage of professionals indicated their disposal properly (90.1\%), [CI 0.878; 0.921]. Doctors, nurses and medical assistants scored $85.7 \%$ [CI $0.755 ; 0.923$ ]; 92.1\% [CI 0.895; 0.941]; and 84.1\% [CI 0.765; 0.897], respectively, showing high or very high percentages. To compare the proportion of success in waste storing by the three professions, the homogeneity test statistic (chi-square of 2 degrees of freedom) was $9.5(\mathrm{p}=0.009)$. This allows the conclusion that significant differences were found between the proportion of success in waste storing by the professionals. For the comparison of the pairs of professions, the values of the chi-square statistics ( 1 degree of freedom) and corresponding p-values were 2.7 (0.100), $0.013(0.908)$, and $7.1(0.008)$ for the comparison of doctors with nurses, doctors with medical assistants, and nurses with medical assistants, respectively. It was possible to conclude that the percentage of correct waste storing by nurses was higher than that of assistants, with no other significant differences found.

8 - Disposable diapers and pads which are contaminated or with traces of blood (Group III, white container) The majority of participants indicated 'White container' (90.9\%), followed by 'Red container' $(4.1 \%)$, 'Black container' (1.9\%) and 'Do not know' (1.3\%), with 15 non-responses found (1.9\%) (Table 1). The statistics of the homogeneity of responses test was $10.4(p=0.006)$, enabling the conclusion that significant differences were found between the professions in waste storing of residues (Table 1).

For comparing doctors with nurses, doctors with medical assistants and nurses with medical assistants, the chi-square statistics and corresponding p-values were respectively 8.7 (0.003), 2.8 (0.094) and 0.1 (0.748), suggesting that the distribution in the case of doctors was different from nurses, with no other differences found. These residues should be stored in the white container. A high percentage of professionals answered this question correctly (90.9\%) [CI 0.886; 0.927]. Doctors, nurses, and medical assistants scored $81.8 \%$ [CI
"Recipiente preto" $(2,7 \%)$ e "Não sabe" (1\%), existindo 8 não respostas (1\%) (Tabela 1$)$.

A estatística do teste da homogeneidade das respostas é $12,7(p=0,013)$, pelo que se conclui que existem diferenças significativas entre as profissões no acondicionamento dos resíduos (Tabela 1). Para a comparação dos médicos com os enfermeiros, dos médicos com os auxiliares de ação médica e dos enfermeiros com os auxiliares de ação médica, os valores das estatísticas do qui-quadrado e correspondentes valores-p são respetivamente $5,1(0,078), 0,9(0,351)$ e $6,7(0,009)$, pelo que se conclui que a distribuição no caso dos médicos não se distingue da distribuição nas outras duas profissões e as distribuições pelos enfermeiros e pelos auxiliares são diferentes.

Estes resíduos constituídos por material de proteção individual em que haja contacto com produtos contaminados (como luvas, máscaras) devem ser acondicionados no recipiente branco, pelo que a proporção de profissionais que os acondicionam corretamente é de 90,1\%, um valor muito elevado, [I.C. $0,878 ; 0,921]$, sendo para os médicos, os enfermeiros e os auxiliares de ação médica respetivamente de $85,7 \%$ [I.C. 0,$755 ; 0,923$ ], 92,1\% [I.C. 0,$895 ; 0,941$ ] e $84,1 \%$ [I.C. 0,$765 ; 0,897]$ constatando-se serem proporções elevadas ou muito elevadas. Para comparar a proporção de sucessos no acondicionamento pelas três profissões, a estatística do teste da homogeneidade (qui-quadrado de 2 graus de liberdade) é $9,5(\mathrm{p}=0,009)$, pelo que se conclui que existem diferenças significativas entre as proporções de sucessos no acondicionamento dos resíduos das profissões. Para a comparação dos pares de profissões, os valores das estatísticas do qui-quadrado (1 grau de liberdade) e correspondentes valores-p são 2,7 $(0,100), 0,013(0,908)$ e $7,1(0,008)$ para a comparação de médicos com enfermeiros, médicos com auxiliares de ação médica e de enfermeiros com auxiliares de ação médica respetivamente. Conclui-se que a proporção de acondicionamento correto dos enfermeiros é superior à dos auxiliares, não se encontrando nenhuma outra diferença significativa.

8- Fraldas e resguardos descartáveis contaminados ou com vestígios de sangue (Grupo III)

O "Recipiente branco" é a resposta maioritária (90,9\%), seguindo-se "Recipiente vermelho" (4,1\%), "Recipiente preto" (1,9\%) e "Não sabe" (1,3\%), existindo 15 não respostas $(1,9 \%)$ (Tabela 1$)$. A estatística do teste da homogeneidade das respostas é $10,4(\mathrm{p}=0,006)$, pelo que se conclui que existem diferenças significativas entre as profissões no acondicionamento dos resíduos (Tabela 1).

Para a comparação dos médicos com os enfermeiros, 
$0.710 ; 0.894], 92.4 \%$ [CI $0.899 ; 0.944$ ] and $89.4 \%$ [CI $0.825 ; 0.939]$, respectively, meaning high or very high percentages.

To compare the proportion of success in waste storing among the three professions, the homogeneity test statistic (chi-square of 2 degrees of freedom) was 9.6 $(p=0.008)$, indicating that significant differences were found between the proportion of success in waste storing of the residues among the professionals. For comparing occupational pairs, the chi-square (1 degree of freedom) and corresponding p-values were $8.2(0.008)$, $1.8(0.180)$, and $0.94(0.333)$ to compare doctors to nurses, doctors to medical assistants and nurses to medical assistants, respectively. It was concluded that the percentage of correct waste storing by doctors is lower than nurses, with no other significant differences found.

9 - Cutting and piercing materials (Group IV, red container)

The majority of participants indicated 'Red container' (96.6\%), followed by "Do not know" (0.8\%), "Black container" and "White container" (0.4\% each), with 15 non-responses found (1.9\%) (Table 1). The homogeneity test was applied since almost all respondents answered 'Red container' for the three professions, and responses for the other containers were not sufficient.

These residues must be stored in the red container. A high percentage of professionals who disposed of them correctly was found $(96.6 \%)$ [CI $0.950 ; 0.977$ ]. Doctors, nurses, and medical assistants scored 93.5\% [CI $0.848 ; 0.976$ ]; $97.4 \%$ [CI $0.957 ; 0.985$ ]; and $94.7 \%$ [CI $0.890 ; 0.977]$, respectively, revealing very high percentages. To compare the proportion of success in storing among the three professions, the homogeneity test statistic (chi-square of 2 degrees of freedom) was 4.8 $(p=0.089)$, with a $p$-value of 0.089 . Therefore, no significant differences were found between the proportion of success in waste storing among professionals. dos médicos com os auxiliares de ação médica e dos enfermeiros com os auxiliares de ação médica, os valores das estatísticas do qui-quadrado e correspondentes valores-p são respetivamente 8,7 $(0,003), 2,8(0,094)$ e $0,1(0,748)$, pelo que se conclui que a distribuição no caso dos médicos é diferente da dos enfermeiros, não havendo quaisquer outras diferenças. Estes resíduos devem ser acondicionados no recipiente branco, pelo que a proporção de profissionais que os acondicionam corretamente é de 90,9\%, um valor muito elevado [I.C.0,886; 0,927], sendo para os médicos, os enfermeiros e os auxiliares de ação médica respetivamente de $81,8 \%$ [I.C.0,710; 0,894], 92,4\% [I.C. 0,$899 ; 0,944$ ] e $89,4 \%$ [I.C.0,825; 0,939], sendo proporções elevadas ou muito elevadas.

Para comparar a proporção de sucessos no acondicionamento entre as três profissões, a estatística do teste da homogeneidade (qui-quadrado de 2 graus de liberdade) é 9,6 ( $\mathrm{p}=0,008)$, pelo que se conclui que existem diferenças significativas entre as proporções de sucessos no acondicionamento dos resíduos das profissões. Para a comparação dos pares de profissões, os valores das estatísticas do qui-quadrado (1 grau de liberdade) e correspondentes valores-p são 8,2 $(0,008)$, $1,8(0,180)$ e $0,94(0,333)$ para a comparação de médicos com enfermeiros, médicos com auxiliares de ação médica e de enfermeiros com auxiliares de ação médica respetivamente. Conclui-se que a proporção de acondicionamento correto pelos médicos é inferior à dos enfermeiros, não se encontrando nenhuma outra diferença significativa.

9 - Materiais cortantes e perfurantes (Grupo IV)

O "Recipiente vermelho" é a resposta maioritária (96,6\%), seguindo-se "Não sabe" $(0,8 \%)$ e "Recipiente preto" e "Recipiente branco" ( $0,4 \%$ cada), existindo 15 não respostas (1,9\%) (Tabela 1). Não é possível efetuar o teste da homogeneidade porque a quase totalidade das respostas se concentra no "Recipiente vermelho" para as três profissões, não existindo um número suficiente de respostas nos outros recipientes.

Estes resíduos devem ser acondicionados no recipiente vermelho, pelo que a observação do quadro mostra que a proporção de profissionais que os acondicionam corretamente é de 96,6\%, um valor muito elevado [I.C. $0,950 ; 0,977]$, sendo para os médicos, os enfermeiros e os auxiliares de ação médica respetivamente de 93,5\% [I.C. 0,848; 0,976], 97,4\% com um I.C. de [I.C $.0,957 ; 0,985]$ e $94,7 \%$ [I.C. 0,$890 ; 0,977$ ], ou seja são proporções muito elevadas. Para comparar a proporção de sucessos no acondicionamento das três profissões, a estatística do teste da homogeneidade (qui-quadrado de 2 graus de liberdade) é $4,8(\mathrm{p}=0,089)$, pelo que 
10 - Empty medicine storage (Group II, black container)

The majority of participants indicated "Black container" (543 professionals or $68.8 \%$ ), followed by "White container" (18.1\%), "Red container" (6.3\%) and "Do not know" (2.8\%), with 31 non-responses (3.9\%) found (Table 1). The statistics for the homogeneity of responses test was 25.3 , with a p-value of approximately 0 ; therefore, it was possible to conclude that there were significant differences in the waste storing among the professionals (Table 1).

For the comparison of doctors with nurses, doctors with medical assistants, nurses with medical assistants, the values of the chi-square statistics and corresponding p-values were, 15.7 (0.000), 24.1 (0.000), and 6.0 (0.049), respectively; suggesting different distributions for doctors compared to both nurses and assistants, also showing no significant distributions for the latter two. These residues must be stored in the black container. The percentage of professionals who disposed of them correctly was $68.8 \%$, which was a moderate value [CI $0.654 ; 0.720]$. Doctors, nurses and medical assistants scored 49.4\% [CI 0.379; 0.609], 70.3\% [CI 0.664; $0.740]$, and $73.5 \%$ [CI.0.650; 0.806], respectively. These data showed a low percentage for doctors, while nurses and medical assistants revealed moderate or rather high percentages. To compare the proportion of success in storing among the three professions, the homogeneity test statistic (chi-square of 2 degrees of freedom) was $15.6(p<0.001)$, with a $p$-value of approximately 0 ; therefore it was possible to conclude that significant differences were found between the proportion of success in the storing of professional waste. For the comparison of pairs of professions, the values of the chi-square statistics ( 1 degree of freedom) and corresponding p-values were 12.8 (0.000), $11.4(0.001)$ and 0.37 (0.541), for the comparison of doctors with nurses, doctors with medical assistants and nurses with medical assistants, respectively. These results suggest that the percentage of correct storing by doctors was lower than nurses and medical assistants and that the latter two show equal percentages. se conclui que não existem diferenças significativas entre as proporções de sucessos no acondicionamento dos resíduos constituídos por materiais cortantes e perfurantes em função das profissões.

10 - Embalagens vazias de medicamentos (Grupo II)

O "Recipiente preto" é a resposta maioritária (543 profissionais ou 68,8\%), seguindo-se "Recipiente branco" (18,1\%), "Recipiente vermelho" $(6,3 \%)$ e "Não sabe" (2,8\%), existindo 31 não respostas $(3,9 \%)$ (Tabela 1). A estatística do teste da homogeneidade das respostas é 25,3, com um valor-p de aproximadamente 0 , pelo que se conclui que existem diferenças significativas entre as profissões no acondicionamento dos resíduos (Tabela 1).

Para a comparação dos médicos com os enfermeiros, dos médicos com os auxiliares de ação médica e dos enfermeiros com os auxiliares de ação médica, os valores das estatísticas do qui-quadrado e correspondentes valores-p são respetivamente 15,7 $(0,000), 24,1(0,000)$ e $6,0(0,049)$, pelo que se conclui que as distribuições no caso dos médicos são diferentes quer das dos enfermeiros, quer dos auxiliares e admite-se que as distribuições destes dois últimos não se distinguem entre si.

Estes resíduos constituídos por embalagens vazias de medicamentos devem ser acondicionados no recipiente preto, pelo que a proporção de profissionais que os acondicionam corretamente é de $68.8 \%$, um valor moderado, [I.C. 0,654; 0,720], sendo para os médicos, os enfermeiros e os auxiliares de ação médica respetivamente de 49,4\% [I.C. 0,379; 0,609], 70,3\% [I.C. 0,664; 0,740] e 73,5\% [I.C $.0,650 ; 0,806]$. A proporção dos médicos é um pouco baixa, sendo as outras duas moderadas ou um pouco elevadas. Para comparar a proporção de sucessos no acondicionamento das três profissões, a estatística do teste da homogeneidade (qui-quadrado de 2 graus de liberdade) é $15,6(p<0,001)$, pelo que se conclui que existem diferenças significativas entre as proporções de sucessos no acondicionamento dos resíduos das profissões. Para a comparação dos pares de profissões, os valores das estatísticas do qui-quadrado (1 grau de liberdade) e correspondentes valores-p são 12,8 $(0,000), 11,4(0,001)$ e $0,37(0,541)$ para a comparação de médicos com enfermeiros, médicos com auxiliares de ação médica e de enfermeiros com auxiliares de ação médica respetivamente. Conclui-se que a proporção de acondicionamento correto dos médicos é inferior à dos enfermeiros e à dos auxiliares e que as proporções destes dois últimos são iguais. 
11 - Cytostatics and all material used in their handling and administration (Group IV, red container)

The majority of participants indicated "Red container" (67.9\%), followed by "White container" (20.5\%), "Do not know" (6.2\%) and "Black container" (1.1\%), with 33 non-responses found (4.2\%) (Table 1).

The statistics for the homogeneity of responses test was 58.4; therefore, it was possible to conclude that significant differences were found in the waste sorting among the professions (Table 1). For the comparison of doctors with nurses, doctors with medical assistants and nurses with medical assistants, the chi-square statistics values and corresponding p-values were, respectively, 43.3 (0.000), 2.2 (0.335), and 28.8 (0.000), suggesting that the sorting in the case of doctors is different from nurses, but not from medical assistants and in the case of nurses it is different from medical assistants.

These residues must be stored in the red container. The percentage of professionals who disposed of them correctly was $67.9 \%$, considered a moderate value [I.C. $0.645 ; 0.712]$. Doctors, nurses and medical assistants scored 44.2\% [I.C. 0.330; 0.559], 75.7\% [I.C. 0.719; 0.791 ] and $47.7 \%$ [I.C. $0.390 ; 0.566$ ], respectively, with nurses showing moderate percentages and low percentages for doctors and medical assistants. To compare the percentage of success in storing among the three professions, the homogeneity test statistic (chi-square of 2 degrees of freedom) was $60.7(\mathrm{p}<0.001)$, indicating significant differences were found between the proportion of success in waste storing. For the comparison of pairs of professions, the values of the chi-square statistics ( 1 degree of freedom) and corresponding p-values were 32.0 (0.000), $0.13(0.722)$ e 39.1 (0.000), referring to the comparison of doctors with nurses, doctors with medical assistants and nurses with medical assistants. It was possible to conclude that the percentage of correct storing by doctors was lower than nurses but equal to medical assistants and that the percentage of nurses was higher than medical assistants.

12 - Non-identifiable anatomical parts (Group III, white container)

The majority of participants indicated "Red container" (53.7\%), followed by "White container" (31.8\%), "Do not know" (9.1\%) and "Black container" (2\%), with 26 non-responses $(2.8 \%)$.

The statistics for the homogeneity of responses test was $57.6(p<0.001)$, indicating significant differences were
11 - Citostáticos e todo o material utilizado na sua manipulação e administração (Grupo IV)

O "Recipiente vermelho" é a resposta maioritária $(67,9 \%)$, seguindo-se "Recipiente branco" (20,5\%), "Não sabe" (6,2\%) e "Recipiente preto" (1,1\%), existindo 33 não respostas (4,2\%) (Tabela 1$)$.

A estatística do teste da homogeneidade das respostas é 58,4 com um valor-p de aproximadamente 0 , pelo que se conclui que existem diferenças significativas entre as profissões no acondicionamento dos resíduos (Tabela 1). Para a comparação dos médicos com os enfermeiros, dos médicos com os auxiliares de ação médica e dos enfermeiros com os auxiliares de ação médica, os valores das estatísticas do qui-quadrado e correspondentes valores-p são respetivamente 43,3 $(0,000), 2.2(0,335)$ e $28,8(0,000)$, pelo que se conclui que a distribuição no caso dos médicos é diferente da dos enfermeiros, mas não se distingue da distribuição dos auxiliares e que as distribuições destes dois últimos são diferentes.

Estes resíduos devem ser acondicionados no recipiente vermelho, pelo que a proporção de profissionais que os acondicionam corretamente é de 67,9\%, um valor moderado, [I.C. 0,645; 0,712], sendo para os médicos, os enfermeiros e os auxiliares de ação médica respetivamente de $44,2 \%$ [I.C. 0,$330 ; 0,559$ ], $75,7 \%$ [I.C. 0,$719 ; 0,791$ ] e $47,7 \%$ [I.C. 0,$390 ; 0,566$ ], sendo a proporção dos enfermeiros moderada, e as outras duas baixas. Para comparar a proporção de sucessos no acondicionamento das três profissões, a estatística do teste da homogeneidade (qui-quadrado de 2 graus de liberdade) é $60,7(p<0,001)$, pelo que se conclui que existem diferenças significativas entre as proporções de sucessos no acondicionamento dos resíduos constituídos por embalagens vazias de medicamentos em função das profissões. Para a comparação dos pares de profissões, os valores das estatísticas do qui-quadrado (1 grau de liberdade) e correspondentes valores-p são 32,0 $(0,000), 0,13(0,722)$ e $39,1(0,000)$ para a comparação de médicos com enfermeiros, médicos com auxiliares de ação médica e de enfermeiros com auxiliares de ação médica respetivamente. Conclui-se que a proporção de acondicionamento correto pelos médicos é inferior à dos enfermeiros, mas é igual à dos auxiliares e que a proporção dos enfermeiros é superior à dos auxiliares.

12 - Peças anatómicas não identificáveis (Grupo III)

O "Recipiente vermelho" é a resposta maioritária $(53,7 \%)$, seguindo-se "Recipiente branco" (31,8\%), "Não sabe" $(9,1 \%)$ e "Recipiente preto" ( $2 \%)$, existindo 26 não respostas $(2,8 \%)$ (Tabela 1$)$.

A estatística do teste da homogeneidade das respostas 
found between the professions in waste storing. For the comparison of doctors with nurses, doctors with medical assistants and nurses with medical assistants, the values of the chi-square statistics and corresponding $\mathrm{p}$ values were $33.3(0.000), 4.5(0.210)$, and $41.3(0.000)$, respectively, enabling theconclusion that the distribution in the case of doctors was different from nurses, but not from assistants and revealing different distributions of the latter two.

These residues must be stored in a white container, and the percentage of correct storing was $31.8 \%$, considered a moderate value [CI 0.286, 0.352]. Doctors, nurses and medical assistants scored 48.1\% [CI 0.366, 0.597 ], $30 \%$ [CI $0.263,0.339$ ], and $30.3 \%$ [0.228, $0.390]$, respectively. It should be noted that the percentage of nurses is moderately low, and the other two were very low. To compare the proportion of success in storing among the three professions, the homogeneity test statistic (chi-square of 2 degrees of freedom) was 10.4, with a p-value of 0.006 , so it was possible to conclude that significant differences were found between the proportion of success in the storing of hospital waste. For the comparison of pairs of professions, the values of the chi-square statistics (1 degree of freedom) and corresponding p-values were 9.3 (0.002), 5.8 (0.016) and $0.000(1.000)$ for the comparison of doctors with nurses, doctors with medical assistants and nurses with medical assistants, respectively. These results suggest that the percentage of correct storing by doctors was higher than nurses and medical assistants and that the percentage of the latter two was equal.

13 - All waste from infectious or suspected patient's rooms, haemodialysis units, autopsy rooms and pathological anatomy (Group IV, white container)

The majority of participants indicated "White container" (60.6\%), followed by "Red container" (31.6\%), "Do not know" (3.7\%) and "Black container" (1.4\%), with 22 non-responses found (2.8\%) (Table 1). The statistics of the homogeneity of responses test was 0.04 ( $p=0.978$ ), so it was possible to conclude that no differences were found in waste storing between the three professions (Table 1).

These residues must be stored in the white container. The percentage of professionals who stored them correctly was $60.6 \%$, considered a moderate value [CI $0.571 ; 0.640]$. Doctors, nurses, and medical assistants é 57,6 ( $\mathrm{p}<0,001)$, pelo que se conclui que existem diferenças significativas entre as profissões no acondicionamento dos resíduos (Tabela 1). Para a comparação dos médicos com os enfermeiros, dos médicos com os auxiliares de ação médica e dos enfermeiros com os auxiliares de ação médica, os valores das estatísticas do qui-quadrado e correspondentes valores-p são respetivamente $33,3(0,000), 4,5(0,210)$ e 41,3 $(0,000)$, pelo que se conclui que a distribuição no caso dos médicos é diferente da dos enfermeiros, mas não se distingue da distribuição dos auxiliares e que as distribuições destes dois últimos são diferentes.

Estes resíduos constituídos por peças anatómicas não identificáveis devem ser acondicionados no recipiente branco, pelo que a proporção de profissionais que os acondicionam corretamente é de 31,8\%, um valor moderado, [I.C. 0,286; 0,352], sendo para os médicos, os enfermeiros e os auxiliares de ação médica respetivamente, de 48.1\% [I.C. 0,366; 0,597], $30 \%$ [I.C. 0,$263 ; 0,339$ ] e $30,3 \%$ [ I.C. 0,$228 ; 0,390$ ], constatando-se que a proporção dos enfermeiros é baixa, moderada, sendo as outras duas muito baixas. Para comparar a proporção de sucessos no acondicionamento das três profissões, a estatística do teste da homogeneidade (qui-quadrado de 2 graus de liberdade) é $10,4(\mathrm{p}=0,006)$, pelo que se conclui que existem diferenças significativas entre as proporções de sucessos no acondicionamento destes resíduos em função das profissões. Para a comparação dos pares de profissões, os valores das estatísticas do qui-quadrado (1 grau de liberdade) e correspondentes valores-p são 9,3 $(0,002), 5,8(0,016)$ e $0,000(1,000)$ para a comparação de médicos com enfermeiros, médicos com auxiliares de ação médica e de enfermeiros com auxiliares de ação médica respetivamente. Conclui-se que a proporção de acondicionamento correto pelos médicos é superior à dos enfermeiros e à dos auxiliares e que as proporções dos dois últimos são iguais.

13 - Todos os resíduos provenientes de quartos de doentes infeciosos ou suspeitos, de unidades de hemodiálise, de salas de autópsia e de anatomia patológica (Grupo III) O "Recipiente branco" é a resposta maioritária $(60,6 \%)$, seguindo-se "Recipiente vermelho" (31,6\%), "Não sabe" $(3,7 \%)$ e "Recipiente preto" $(1,4 \%)$, existindo 22 não respostas $(2,8 \%)$ (Tabela 1$)$. A estatística do teste da homogeneidade das respostas é $0,04(\mathrm{p}=0,978)$, pelo que se admite que não existem diferenças entre as três profissões no acondicionamento dos resíduos (Tabela 1).

Estes resíduos devem ser acondicionados no recipiente branco, pelo que a proporção de profissionais que os acondicionam corretamente é de $60,6 \%$, um valor 
scored 58.4\% [CI. 0.466; 0.694]; 61.6\% [CI. 0.574; 0.655]; and 57.6\% [CI. 0.487; 0.660], respectively, all moderate percentages. In order to compare the proportion of success in storing among the three professions, the homogeneity test statistic (chi-square of 2 degrees of freedom) was $0.88(\mathrm{p}=0.645)$, so it was possible to conclude that no significant differences were found between the proportion of success of waste storing by the professionals.

The presented data regarding the sorting and storing practices of the $13 \mathrm{HW}$ types surveyed demonstrated that health professionals have sufficient knowledge, showing that $68.77 \%$ perform the sorting and storing adequately. About $25 \%$ of respondents demonstrated poor knowledge evidencing incorrect practices, and $3.7 \%$ revealed a total lack of information. Referring to the total of responses analysed, three types of HW were identified to which the professionals did not respond correctly, namely, rejected drugs (47.8\%) (Group IV), uncontaminated serum bottles (46.1\%) (Group II), and unidentifiable anatomical parts (53.7\%) (Group III), showing that the professionals lack of knowledge is significant, especially in Groups III and IV (these being the higher risk groups).

For the remaining $10 \mathrm{HW}$ subtypes surveyed, although the majority of responses revealed knowledgeable practices, there was still a significant number of non-conforming responses, namely, uncontaminated orthopaedic material with no blood traces, $27.6 \%$, identifiable anatomical parts, $25.9 \%$, and waste from infectious patient rooms, 33\%, responses (group IV and III respectively), which is in line with other studies $(2,14)$.

In the thirteen HW subtypes, the response "Do not know" showed a significant percentage with emphasis on the following HW: anatomical parts not identifiable $18.7 \%$, identifiable parts $17.4 \%$, the rejected drugs $13.2 \%$, cytostatics $12.7 \%$, orthopaedic material $10.1 \%$. The remaining residues had an expression of less than $10 \%$. The percentage of "Do not know" responses were more significant in Groups III and IV (higher risk groups) except for orthopaedic material of Group II. In this context, all the questions obtained non-responses. Considering some previous studies $(2,14)$, the percentages of sorting, improper storing. and lack of knowledge are more significant in Groups III and IV, with nurses indicated to be the better informed group, followed by medical assistants and doctors, as was shown in this work. This might be explained by the fact that the functional content of each of these professionals en- moderado [I.C. 0,571; 0,640], sendo para os médicos, os enfermeiros e os auxiliares de ação médica respetivamente de $58,4 \%$ [I.C. 0,$466 ; 0.694$ ], $61,6 \%$ [I.C. 0,$574 ; 0,655$ ] e $57,6 \%$ [I.C. 0,$487 ; 0,660$ ], ou seja são proporções moderadas. Para comparar a proporção de sucessos no acondicionamento das três profissões, a estatística do teste da homogeneidade (qui-quadrado de 2 graus de liberdade) é 0,88 ( $\mathrm{p}=0,645)$, pelo que se conclui que não existem diferenças significativas entre as proporções de sucessos no acondicionamento dos resíduos em função das profissões.

Os dados apresentados relativamente às práticas de triagem e acondicionamento dos $13 \mathrm{RH}$ questionados demonstram que existe conhecimento adequado por parte dos profissionais de Saúde, 68,77\% realizam a triagem e acondicionamento adequadamente. Cerca de $25 \%$ não manifesta conhecimento adequado evidenciando práticas incorretas, e 3,7\% revela desconhecimento das mesmas.

No total das respostas analisadas, existem três tipos de RH em que os profissionais não responderam corretamente, respetivamente, fármacos rejeitados $(47,8 \%)$ - grupo IV, frascos de soro não contaminados $(46,1 \%)$ - grupo II peças anatómicas não identificáveis $(53,7 \%)$ - grupo III, mostra que o desconhecimento dos profissionais é significativo e com maior significância nos grupos III e grupo IV (grupos de maior risco).

Relativamente aos restantes 10 subtipos de RH questionados, apesar de as respostas de acondicionamento adequado serem as que estão em maior frequência, existe ainda um número de respostas não conformes significativo, respetivamente material ortopédico não contaminado e sem vestígios de sangue, $27,6 \%$, peças anatómicas identificáveis, $25,9 \%$, e os resíduos provenientes de quartos de doentes infeciosos, $33 \%$, de respostas (grupo IV e III respetivamente), tal como em outros estudos realizados $(2,14)$.

Nos treze subtipos de RH, a resposta «não sabe» apresenta uma percentagem significativa com destaque para os seguintes RH: peças anatómicas não identificáveis $18,7 \%$, as peças identificáveis $17,4 \%$ os fármacos rejeitados $13,2 \%$, os citostáticos $12,7 \%$, o material ortopédico $10,1 \%$. Os restantes resíduos apresentam uma expressão inferior a $10 \%$. A percentagem das respostas "não sabe" são mais significativas nos grupos III e IV (grupos de maior risco) com exceção do material ortopédico que pertence ao Grupo II. Neste contexto, saliente-se que todas as questões apresentam não respostas.

Considerando estudos já realizados $(2,14)$, as percentagens de triagem eacondicionamento inadequado 


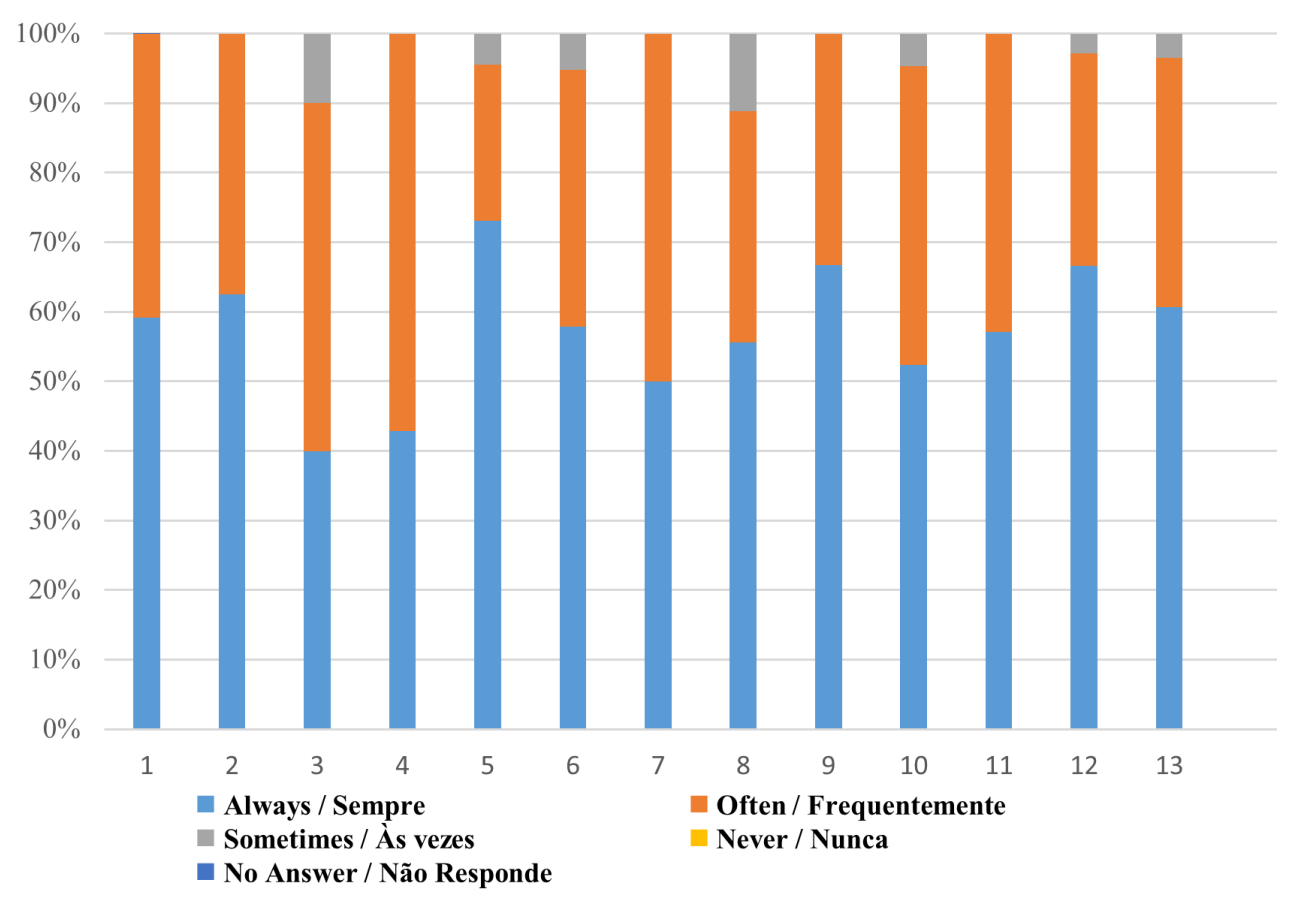

Figure 2 - Frequency of contact related to professionals who dispose inadequately

Figura 2 - Frequência de contacto relativo aos profissionais que acondicionam inadequadament

Legend / Legenda

1. Rejected medication / Fármacos (medicamentos) rejeitados.

2. Waste from general services / Resíduos provenientes de serviços gerais.

3. Organic fluid collection bags and respective systems / Sacos coletores de fluidos orgânicos e respetivos sistemas.

4. Uncontaminated serum bottles, already used / Frascos de soros não contaminados, já utilizados.

5. Identifiable anatomical parts, fetuses, and placentas / Peças anatómicas identificáveis, fetos e placentas.

6. Orthopedic material (with splints and plaster) not contaminated and without a trace of blood / Material ortopédico (como talas e gesso) não contaminado e sem vestígios de sangue.

7. Personal protective material which has been in contact with contaminated products / Material de proteção individual em que haja contacto com produtos contaminados.

8. Disposable diapers and pads contaminated or with traces of blood / Fraldas e resguardos descartáveis contaminados ou com vestigios de sangue.

9. Cutting and piercing materials / Materiais cortantes e perfurantes.

10. Empty medicine packaging / Embalagens vazias de medicamentos.

11. Cytostatics and all the material used in their handling and administration / Citostáticos e todo o material utilizado na sua manipulação e administração.

12. Non identifiable anatomical parts / Peças anatómicas não identificáveis.

13. Waste from infectious patients / Resíduos provenientes de doentes infeciosos.

compasses different types of procedures/tasks of logistic management.

In summary, this study confirmed the importance of analysing the situation of professionals who present noncompliant practices regarding the sorting and storing of HW and the impact of the knowledge evidence-based, given the frequency of contact with this type of waste. The list of responses showed that the knowledge gap relating to some of the items (already mentioned), as demonstrated by professionals through non-compliant responses, occurs in those who are (in terms of prevalence) always or often in contact with the specific type of HW (Figure 2). The highest percentages were found in Identifiable Anatomical Parts (73.1\%), Cutting and e de desconhecimento, são mais significativas nos grupos III e IV, verificando-se que os Enfermeiros são o grupo que apresenta maior informação seguido dos Auxiliares e Médicos, tal como neste trabalho. A justificação para esta constatação prende-se com o conteúdo funcional de cada um destes profissionais que engloba diferentes tipos de procedimentos/tarefas de gestão logística no âmbito do seu conteúdo funcional. Em resumo, confirma-se a importância de analisar a situação dos profissionais que apresentam práticas não conformes relativamente à triagem e acondicionamento dos $\mathrm{RH}$ e o impacto do conhecimento evidenciado face à frequência de contato com este tipo de resíduos. A relação das respostas permitiu constatar que a lacuna 
Punching Materials and Non-Identifiable Anatomical Parts $(66.7 \%)$.

Notably, in terms of contact, the answer "Sometimes" is only related to questions addressing the identifiable anatomical parts, foetuses and placentas, empty storing of medicines, uncontaminated orthopaedic material with no traces of blood, collection bags and diapers and contaminated disposable pads, with emphasis on the latter two, with percentages of $10 \%$ and $5.1 \%$, respectively (Figure 2) .

\section{Conclusion}

Hospital Waste sorting and storing is one of the most critical phases of the HW management process and a key factor to minimize the impact in public and environmental health. Health professionals play an important role in the effective management of this process. Their involvement is crucial and should be based on a socio-technical perspective. Although $68.77 \%$ of health professionals participating in this study showed adequate knowledge regarding the sorting and storing of hospital waste, a considerable percentage of professionals were still poorly prepared (over $25 \%$ ) and $3.7 \%$ revealed lack of knowledge about these processes. Importantly, the main gaps in knowledge were found to be most significant in HW Groups III and IV, those considered to be more exposed to hazardous risk.

These study findings enabled to identify recurrent mistakes in waste management despite the professionals' everyday contact with HW. Therefore, specific knowledge and awareness about inappropriate practices need to be carefully examined. Together, the issues related to knowledge and associated practices pertaining to the human factor are considered one of the main barriers in HW management $(15,16)$, calling attention to the importance of developing continuous training programmes and audits to implemented waste management systems. de conhecimento demostrada pelos profissionais em alguns dos itens (já mencionados) através das respostas não conformes, ocorre nos profissionais que estão em termos de prevalência sempre ou frequentemente em contacto com a tipologia de RH questionada (Figura 2). As percentagens mais elevadas constatam-se nas Peças anatómicas identificáveis $(73,1 \%)$; e nos Materiais Cortantes e perfurantes e peças anatómicas não identificáveis $(66,7 \%)$.

Saliente-se que só nas questões relacionadas com as peças anatómicas identificáveis fetos e placentas, embalagens vazias de medicamentos, material ortopédico não contaminados e sem vestígios de sangue, sacos coletores e fraldas e resguardos descartáveis contaminados é que ocorre em termos de contacto "às vezes" por parte dos profissionais com destaque para estes dois últimos com percentagens de $10 \%$ e $5,1 \%$ respetivamente (Figura 2).

\section{Conclusões}

A triagem e acondicionamento dos Resíduos Hospitalares é uma das fases mais importantes do processo de gestão de RH de forma a minimizar o impacto dos seus riscos quer a nível da Saúde Publica quer a nível da Saúde Ambiental. Os principais intervenientes nesta fase são os profissionais de saúde tornando-se imperativo o envolvimento dos mesmos em toda a gestão efetiva, tendo como base uma perspetiva sociotécnica. Apesar de 68,77\% dos profissionais de saúde que participaram neste estudo evidenciarem um conhecimento adequado relativo à triagem e acondicionamento de resíduos hospitalares, ainda existe uma percentagem considerável de profissionais com práticas de triagem inadequadas (mais de $25 \%$ ) e desconhecimento das mesmas $(3,7 \%)$. A principais lacunas de conhecimento são mais significativas nos grupos III e IV considerados os de maior risco.

Verificamos que apesar do contacto continuado com os $\mathrm{RH}$ e os erros de triagem diagnosticados, é evidente a necessidade de aquisição de conhecimentos específicos bem como de consciencialização sobre uma prática inadequada. $\mathrm{O}$ fator humano, nomeadamente as questões relacionadas com o conhecimento e as práticas associadas, são consideradas, no seu conjunto, uma das principais barreiras no sistema de gestão de RH $(15,16)$ suscitando a importância de programas de formação contínua e auditorias aos sistemas de gestão de resíduos. 


\section{Acknowledgements}

The authors would like to express their gratitude to the Board of Directors of North Central Hospital for having approved the research project underlying this work.

\section{Author's Contributions}

BE - Conception, structure, data analysis and review BM - Data analysis and review MS - Figures and tables and review MCC - structure, data analysis and review

\section{Conflicts of Interest}

The authors declare no potential conflict of interest.

\section{Agradecimentos}

Os autores gostariam de expressar os seus agradecimentos à Direção do Centro Hospitalar Central do Norte pela aprovação do projeto de investigação subjacente a este trabalho.

\section{Declaração Sobre as Contribuições dos Autores}

BE - Conceção, estrutura, analise de dados e revisão BM - Analise de dados e revisão MS - Figuras e tabelas e revisão $\mathrm{MCC}$ - estrutura, analise de dados e revisão

\section{Conflitos de Interesses}

Os autores declaram que não tem qualquer relação de potencial conflito de interesses. 


\section{References / Referências}

1. Edra B, Gestão de Resíduos Hospitalares: Estudo de referências de boas práticas, com base na perceção e avaliação de risco de exposição ocupacional num Hospital Central. Tese de Doutoramento, Universidade de Alcalá de Henares / Universidade Lusófona; 2019.

2. Ferreira V, Avaliação das Práticas de Gestão de Resíduos Hospitalares, Risco e Perceção de Risco Associado. Dissertation presented in the scope of the Integrated Master in Environmental Engineering in the area of Environmental Technologies by Universidade do Algarve; 2009.

3. Fazzo L, Minichilli F, Santoro M, Ceccarini A, Della MD, Bianchi F, Comba P, Martuzzi M, Hazardous waste and health impact: a systematic review of the scientific literature, Environ Health; 2017; 16: 107-118.

4. Jindal AK, Gupta A, Grewal VS, Mahen A, Biomedical waste disposal: A systems analysis, Med J Armed Forces India; 2013; 69(4): 351-356.

5. Kumar SP, Biomedical Waste Management: Regulation, Guideline and Review, BFUNJ; 2016; 11(2): 1-5.

6. Costa WM, Fonseca MCG, A importância do gerenciamento dos resíduos hospitalares e seus aspetos positivos para o meio Ambiente, HYGEIA, Revista Brasileira de Geografia Médica e da Saúde; 2009; 5(9): 12-31.

7. Durães NNM, A Eficácia da Triagem dos Resíduos Hospitalares como redução de custos em Saúde. Tese de Mestrado, Instituto Superior de Ciências Sociais, Universidade de Lisboa; 2014.

8. Direção Geral de Saúde, Resíduos hospitalares - Documento de Orientação; Direção Geral da Saúde, Divisão de Saúde Ambiental e Ocupacional; 2009.

9. Pinzone M., Lettieri E, Masella C, Proactive Environmental Strategies in Healthcare Organisations: Drivers and Barriers in Italy, J Bus Ethics 2015; 131: 83-197.

10. Mendes WC et al, Conhecimento e prática de trabalhadores, profissionais e gestores sobre os resíduos de serviços de Saúde. Research magazine Cuidado é Fundamental Online [Internet]; 2015; 7(4): 3216-3226.

11. Botelho A, Determinants of compliance with healthcare waste management regulations by European private healthcare Facilities, Int J Chem and Environ, Eng Sys, 2012, 3: 74-84.

12. Chang $\mathrm{CH}$, Chiao YC, Tsai Y, Identifying competitive strategies to improve the performance of hospitals in a competitive environment, BMC Health Serv Res.; 2017; 17: 756-766.

13. Ozder A, Teker B,Eker, HH, Altindis S, Kocaakman, M, Karabay O, Medical waste managment training for healthcare managers - a necessity?, J Environ Health Sci Eng. 2013, 11(1): 11-20.

14. Gonçalves M G, Gestão de Resíduos Hospitalares: Conhecimentos, Opções e Perceções dos Profissionais de Saúde. Tese de Doutoramento, Universidade Nova de Lisboa; 2005.

15. Diego VGD et al, Waste management barriers in developing country hospitals: Case study and AHP analysis, Waste Manag Res; 2017, 36(1): 48-58.

16. Banstola D et al, Knowledge, Attitude and Practice of Health Care Institutions and their Staff Involved in Hospital Solid Waste Management, J Inst Med 2017; 39(3): 47-52. 